\title{
IgG4-related diffuse perineural disease
}

Figure 1 Imaging findings of nerve roots

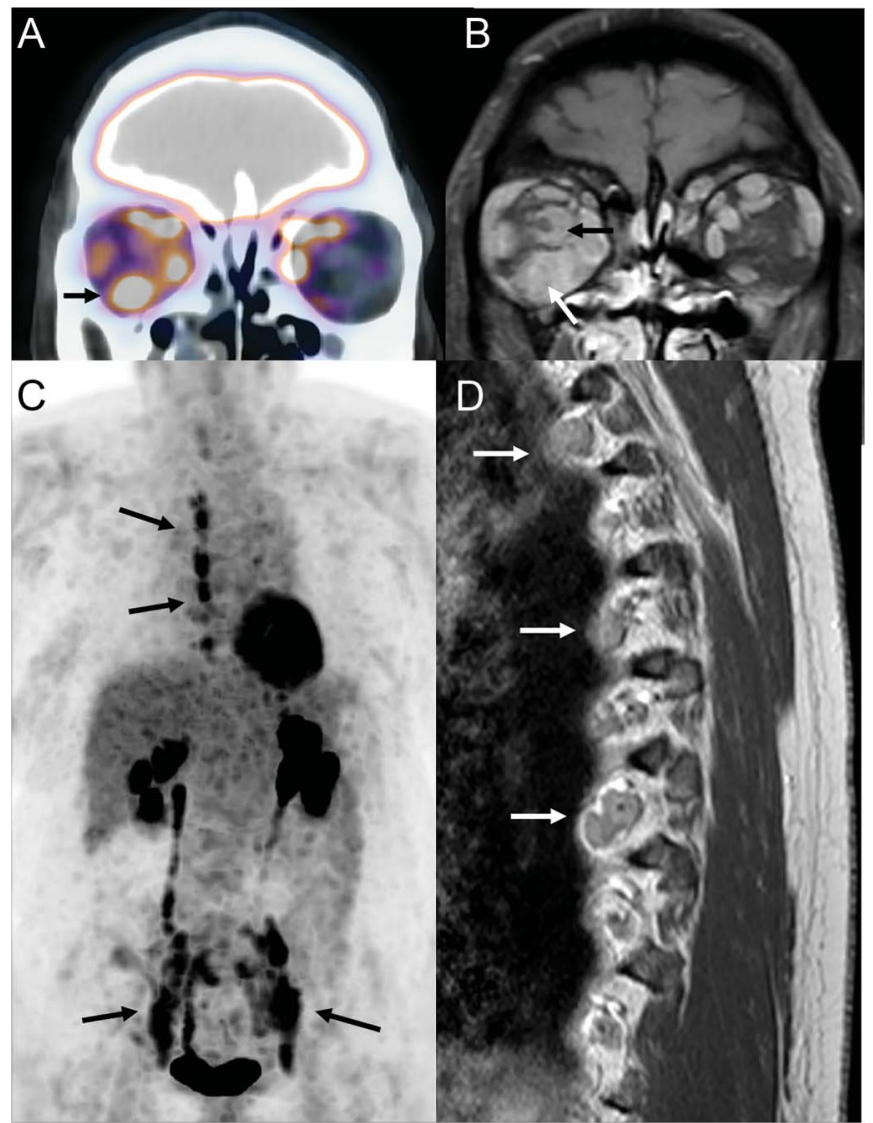

Right orbit (A) and paravertebral (C) FDG uptakes (SUV max = 7). MRI shows meningeal infiltration of the right optic nerve ( $B$, black arrow), a thickening of inferior orbital muscle ( $B$, white arrow), and a diffuse infiltration of paravertebral nerve roots (D).

A 55-year-old woman had right exophthalmia. Eleven years previously, she had orbital irradiation for refractory nonspecific orbital inflammation. PET/CT revealed FDG uptake in the right orbit and paravertebral masses (figure 1, A and C). MRI showed an enlargement of the right optic nerve and orbital muscles, and a diffuse infiltration involving lumbodorsal and sacral nerve roots (figure 1, B and D). The orbital biopsy demonstrated immunoglobulin G4 (IgG4) + plasma cell infiltrate and a storiform fibrosis (figure 2), identical to the histopathologic features of the nerve root biopsy, and suggestive of IgG4-related diffuse perineural disease. ${ }^{1,2}$ No treatment was started in the absence of neurologic symptoms. One year later, the patient had no further symptoms.

Michael Soussan, MD, Aicha Medjoul, MD, Isabelle Badelon, MD, Alexis Guillot, MD, Antoine Martin, MD, PhD, Sébastien Abad, MD, PhD

From the Departments of Nuclear Medicine (M.S.), Radiology (A. Medjoul), Ophtalmology (I.B.), Dermatology (A.G.), Pathology (A. Martin), and Internal Medicine (S.A.), Université Paris 13, Faculté Léonard de Vinci, Hôpital Avicenne, Assistance Publique-Hôpitaux de Paris (AP-HP), Paris, France. 


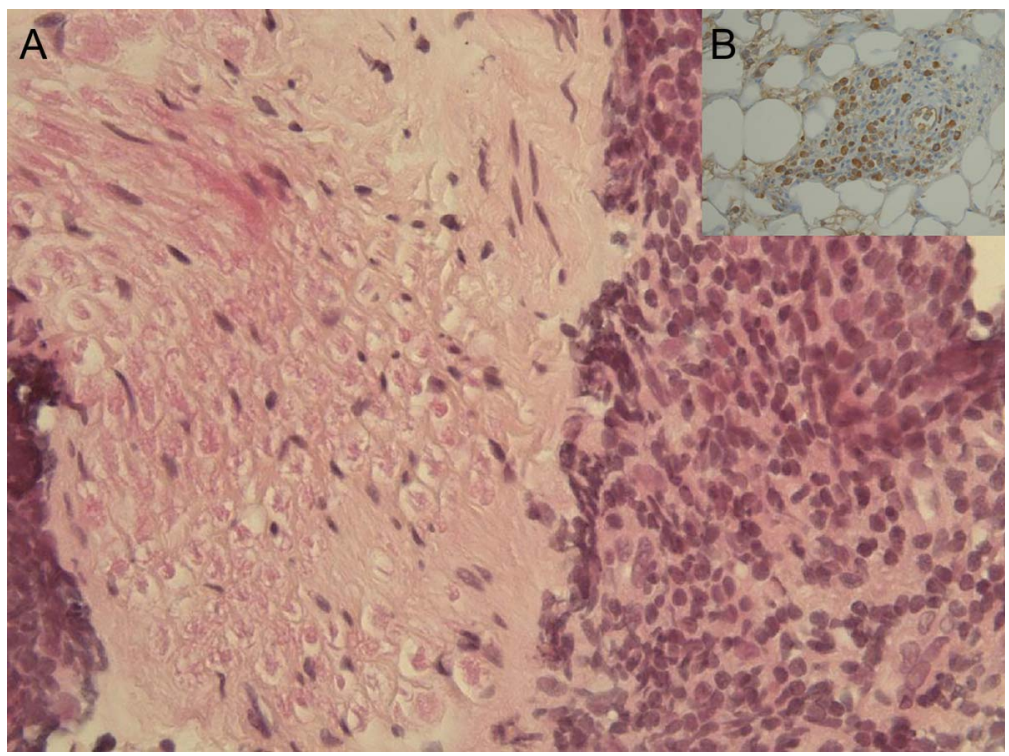

A perineural lymphoplamacytic infiltrate was observed. Note that endoneurium is unremarkable without inflammatory cell infiltration (A, hematoxylin \& eosin $\times 40$ ). Immunohistochemical staining for immunoglobulin G4 (IgG4) revealed approximatively 50 lgG4-positive plasma cells/high-power field (B, immunoperoxidase $\times 40$ ).

Author contributions: Michael Soussan: study concept and design, study supervision. Aicha Medjoul: acquisition of data, analysis and interpretation. Isabelle Badelon: acquisition of data, analysis and interpretation. Alexis Guillot: acquisition of data, analysis and interpretation. Antoine Martin: acquisition of data, analysis and interpretation, study supervision. Sébastien Abad: study concept and design, acquisition of data, analysis and interpretation, study supervision.

Study funding: No targeted funding reported.

Disclosure: The authors report no disclosures relevant to the manuscript. Go to Neurology.org for full disclosures.

Correspondence to Dr. Soussan: michael.soussan@avc.aphp.fr

1. Inoue D, Zen Y, Sato Y, et al. IgG4-related perineural disease. Int J Rheumatol 2012;2012:401890.

2. Wallace ZS, Deshpande V, Stone JH. Ophthalmic manifestations of IgG4-related disease: single-center experience and literature review. Semin Arthritis Rheum 2014;43:806-817.

\section{WriteClick ${ }^{\circledR}$ rapid online correspondence}

The editors encourage comments about recent articles through WriteClick:

Go to Neurology.org and click on the "WriteClick" tab at the top of the page. Responses will be posted within 72 hours of submission.

Before using WriteClick, remember the following:

- WriteClick is restricted to comments about studies published in Neurology within the last eight weeks

- Read previously posted comments; redundant comments will not be posted

- Your submission must be 200 words or less and have a maximum of five references; reference one must be the article on which you are commenting

- You can include a maximum of five authors (including yourself) 


\title{
Neurology
}

\author{
IgG4-related diffuse perineural disease \\ Michael Soussan, Aicha Medjoul, Isabelle Badelon, et al. \\ Neurology 2014;83;1877-1878 \\ DOI 10.1212/WNL.0000000000000979
}

This information is current as of November 10, 2014

$\begin{array}{ll}\begin{array}{l}\text { Updated Information \& } \\ \text { Services }\end{array} & \begin{array}{l}\text { including high resolution figures, can be found at: } \\ \text { http://n.neurology.org/content/83/20/1877.full }\end{array} \\ \text { References } & \text { This article cites } 2 \text { articles, } 0 \text { of which you can access for free at: } \\ \text { http://n.neurology.org/content/83/20/1877.full\#ref-list-1 } & \text { This article, along with others on similar topics, appears in the } \\ \text { following collection(s): } & \text { Autoimmune diseases } \\ \text { http://n.neurology.org/cgi/collection/autoimmune_diseases } & \text { MRI } \\ \text { http://n.neurology.org/cgi/collection/mri } & \text { PET } \\ & \text { http://n.neurology.org/cgi/collection/pet } \\ & \text { An erratum has been published regarding this article. Please see next } \\ \text { page or: } & \text { /content/84/5/547.2.full.pdf } \\ & \text { Information about reproducing this article in parts (figures,tables) or in } \\ \text { Errata } & \text { its entirety can be found online at: } \\ & \text { http://www.neurology.org/about/about_the_journal\#permissions } \\ \text { Permissions \& Licensing } & \text { Information about ordering reprints can be found online: } \\ & \text { http://n.neurology.org/subscribers/advertise }\end{array}$

Neurology ${ }^{\circledR}$ is the official journal of the American Academy of Neurology. Published continuously since 1951, it is now a weekly with 48 issues per year. Copyright (O 2014 American Academy of Neurology. All rights reserved. Print ISSN: 0028-3878. Online ISSN: 1526-632X.

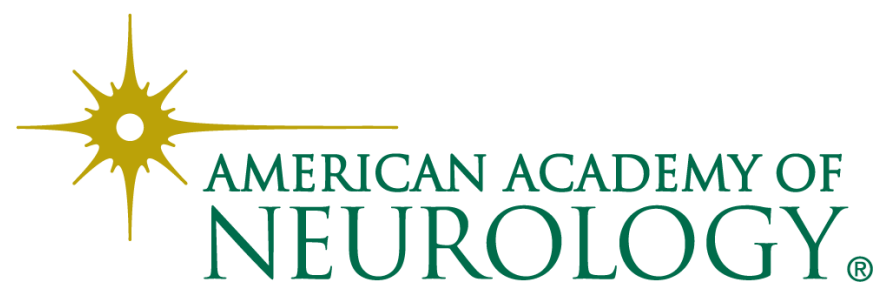


MYSTERY CASE: PENDULAR SEE-SAW

NYSTAGMUS AS A DELAYED COMPLICATION OF TRAUMATIC BRAIN INJURY

Eric R. Eggenberger, East Lansing, MI: I read with interest the delayed see-saw nystagmus case detailed by Yunusov et al. ${ }^{1}$ We also published 2 delayed cases occurring 21 and 37 years post head trauma involving the chiasmal region. ${ }^{2}$ Both patients exhibited bitemporal hemianopia and MRIs suggestive of chiasmal disruption; one case experienced a modest response to clonazepam. The mechanism of delayed onset neuro-ophthalmic syndromes and the more familiar oculopalatal tremor are unclear, but may be more common than previously thought.

(C) 2015 American Academy of Neurology

1. Yunusov F, Park JH, Huh YE, Kim HJ, Kim JS. Mystery Case: Pendular see-saw nystagmus as a delayed complication of traumatic brain injury. Neurology 2014;82:e147-e148.

2. Eggenberger E. Delayed-onset seesaw nystagmus posttraumatic brain injury with bitemporal hemianopia. Ann NY Acad Sci 2002;956:588-591.

\section{CORRECTION}

In the NeuroImage "IgG4-related diffuse perineural disease" by M. Soussan et al. (Neurology ${ }^{\circledR} 2014 ; 83: 1877-1878$ ), there is a misspelling in the byline. The fourth author's name should read "Alexis Guyot, MD," rather than "Guillot" as originally published. The authors regret the error. 